\title{
The roles of PDGF in Development and During Neurogenesis in the Normal and Diseased Nervous System
}

\author{
Keiko Funa $\cdot$ Masakiyo Sasahara
}

Received: 25 April 2013 / Accepted: 23 May 2013 /Published online: 15 June 2013

(C) The Author(s) 2013. This article is published with open access at Springerlink.com

\begin{abstract}
The four platelet-derived growth factor (PDGF) ligands and PDGF receptors (PDGFRs), $\alpha$ and $\beta$ (PDGFRA, PDGFRB), are essential proteins that are expressed during embryonic and mature nervous systems, i.e., in neural progenitors, neurons, astrocytes, oligodendrocytes, and vascular cells. PDGF exerts essential roles from the gastrulation period to adult neuronal maintenance by contributing to the regulation of development of preplacodal progenitors, placodal ectoderm, and neural crest cells to adult neural progenitors, in coordinating with other factors. In adulthood, PDGF plays critical roles for maintenance of many specific cell types in the nervous system together with vascular cells through controlling the blood brain barrier homeostasis. At injury or various stresses, PDGF modulates neuronal excitability through adjusting various ion channels, and affecting synaptic plasticity and function. Furthermore, PDGF stimulates survival signals, majorly PI3K/Akt pathway but also other ways, rescuing cells from apoptosis. Studies imply an involvement of PDGF in dendrite spine morphology, being critical for memory in the developing brain. Recent studies suggest association of PDGF genes with neuropsychiatric disorders. In this review, we will describe the roles of PDGF in the nervous system, from the discovery to recent findings, in order to understand the broad spectrum of PDGF in the nervous system. Recent development of pharmacological and replacement therapies targeting the PDGF system is discussed.
\end{abstract}

Keywords PDGF · PDGFRA $\cdot$ PDGFRB · Nervous system

\footnotetext{
K. Funa $(\bowtie)$

Sahlgrenska Cancer Center, University of Gothenburg

Box 425, SE 405 30, Gothenburg, Sweden

e-mail: keiko.funa@gu.se

M. Sasahara

Department of Pathology, Graduate School of Medicine and

Pharmaceutical Sciences, University of Toyama

Toyama 930-0152, Japan

\section{Introduction}

Platelet-derived growth factor (PDGF) family members include PDGF-A, -B, -C and -D, which are assembled as disulfide-linked homo- or heterodimers. There exist two types of PDGF receptors (PDGFR- $\alpha,-\beta$ ), the PDGFRA binding A-, $\mathrm{B}$ - and C-chains, while the PDGFRB binds B- and D-chains, as reviewed (Shim et al. 2010; Heldin 2012). PDGF-AB, the only heterodimer known to exist so far, was first purified from human platelets and considered to be a growth factor necessary for growth and migration of mesenchymal cells (Hammacher et al. 1988). Most mesenchymal cells express both receptors, and the expression is increased in wound healing and inflammation, especially in chronic inflammatory diseases, i.e., atherosclerosis, rheumatoid arteritis, and nephritis (Heldin and Westermark 1999). All these chains are synthesized as precursor forms and cleaved during secretion by proteolytic enzymes, except for PDGF-C (Shim et al. 2010).

The recently identified members differ from the traditional A- and B-chains, in that PDGF-C and D-chains possess a long N-terminal CUB (complement protein $\mathrm{C} 1 \mathrm{r} / \mathrm{C} 1 \mathrm{~s}$, Uegf, and Bmp1) domain, which has to be cleaved for binding to receptors (Li et al. 2000; Bergsten et al. 2001; LaRochelle et al. 2001; Fredriksson et al. 2004; Reigstad et al. 2005). Structurally, PDGF-C protein may be closer to VEGF-A than to PDGF-B. PDGFR and VEGFR also resemble each other structurally, and VEGF-A is reported to activate PDGFR (Ball et al. 2007; Pfister et al. 2012). Binding of a dimerized PDGF-ligand causes receptor dimerization, which induces autophosphorylation of intracellular kinases, activating the downstream signaling molecules that bind to phosphorylated tyrosine residues of the intracellular domain of PDGF receptors in order to propagate signals (Shim et al. 2010; Heldin 2012). All four chains and the receptors are expressed in the nervous system, and PDGFRA and -RB transduce overlapping, but distinctive signals (Heldin et al. 
1998; Andrae et al. 2008; Ishii et al. 2008; Yao et al. 2009; Zheng et al. 2010). A schematic drawing on the PDGF system is shown in Fig. 1. In this review, we focus on the roles of PDGF in the nervous system.

\section{O-2A cells and oligodendrogenesis}

The first significant paper that revealed the role of PDGF in the nervous system reported the identification of bipotential progenitors isolated from rat postnatal optic nerve, giving rise to oligodendrocytes and type- 2 astrocytes (O-2A cells) in culture (Raff et al. 1988; Richardson et al. 1988). The O2A cells were shown to divide several times in PDGFcontaining media until cells intrinsically initiate differentiation, but $\mathrm{O}-2 \mathrm{~A}$ cells can be maintained as progenitors in the presence of both PDGF and FGF (Bogler et al. 1990).

The type-2 astrocyte is distinguished from the so-called type-1 astrocyte, which arises earlier and developing from its own progenitor. The type- 1 and type- 2 astrocytes also differ in their growth factor requirement, morphology, and in vivo localization (Raff and Lillien 1988). Type-1 astrocytes secrete PDGF-AA stimulating O-2A to proliferate via the expression of PDGFRA (Richardson et al. 1988). The study has brought about an essential notion of the existence of PDGF-responsive bipotential progenitors from the nervous system, precisely and timely regulated by different soluble factors as for proliferation and differentiation. As O-2A adult progenitors seem to cycle slowly and divide and differentiate asymmetrically, thus having the capacity of self-renewal, reviewed by (Noble et al. 2003). So far, different types of oligodendrocyte progenitors have been identified (reviewed by Polito and Reynolds 2005).

PDGF-responsive precursors were isolated from human embryonic brain tissues by neurosphere cultures, which could differentiate into oligodendrocytes, astrocytes and even neurons, albeit with less efficiency (Chojnacki and Weiss 2004; Chojnacki et al. 2008). The best combination of growth factors for these progenitors is shown to be bFGF and EGF, when neural stem cells are maintained in the self-renewing conditions. However, EGF without FGF appears to induce astrocytes (Chojnacki et al. 2008). Upon factor withdrawal, most of the cells differentiate into neurons and some into astrocytes. However, neural stem cells maintained with PDGF-AA in vitro differentiate to neurons or oligodendrocytes.

There are significant differences in oligodendrocyte progenitor cells between rodent and human, as well as those of fetal and adult. However, all PDGF-responsive precursors require FGF2 and PDGF, which induce sonic hedgehog signaling, to maintain self-renewal, similar to the cephalic multipotent neural crest stem cells (Dupin et al. 2010). Interestingly, an adult human corpus callosum showed that PDGFRA and FGFR2 expressing cells colocalized in the same cells (Chojnacki et al. 2008). Another study demonstrated that mice subventricular zone (SVZ)-GFAP-positive neural stem cells could also migrate into the corpus callosum and fimbria fornix, to generate a small number of non-myelinating NG2-positive oligodendrocyte progenitor cells and mature myelinating oligodendrocytes (Menn et al. 2006). Fetal human forebrain- or iPS-derived oligodendrocyte progenitors enriched by PDGFRA (CD140a ${ }^{+}$) have
Fig. 1 Schematic illustration of the hetero- and homodimers of PDGF, and their binding receptors. The major PDGF intracellular receptor binding signaling molecules are shown together with possible other receptors interplaying with PDGF receptors. Examples of the cells expressing different PDGF-receptor combinations are mentioned under the each combination of the receptors. P; phosphorylation, $\mathrm{Ch}$; channel

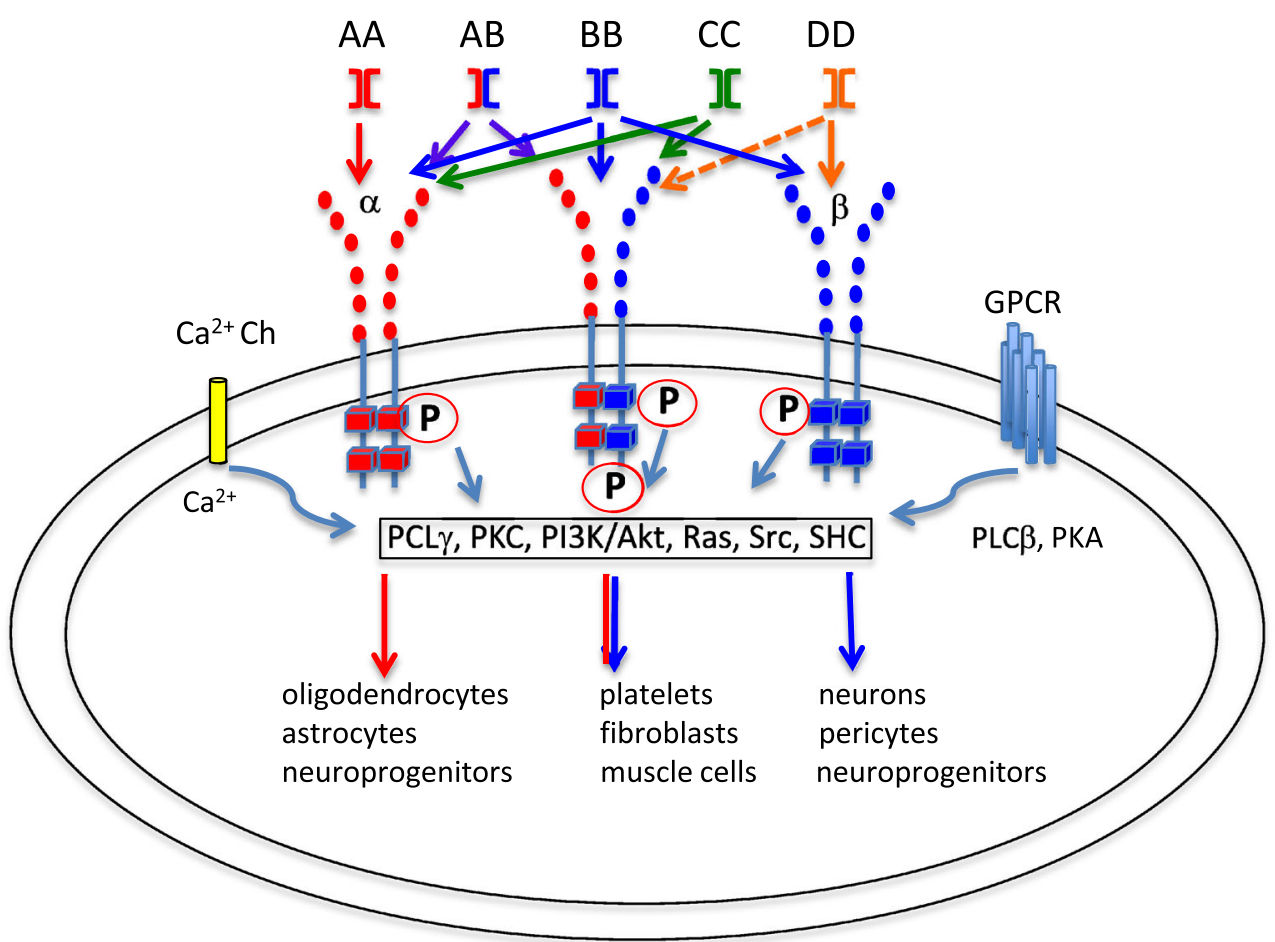


been shown to be most effective in both myelinating and migratory capacities, compared with those selected by A2B5, when transplanted to hypomyelinated shiverer mouse brain. This suggests the myelin disorders as promising targets of cell-based therapy (Mazzarella et al. 2011; Goldman et al. 2012). Recent studies on in vivo grafts confirm that PDGF-responsive neural precursors differentiate into myelinating oligodendrocytes in spinal cord-contused adult rats and dysmyelinated mice (Plemel et al. 2011).

\section{Phenotypes of PDGF and its receptors in KO mice}

In order to understand the individual roles of PDGFRs, experiments have been carried out on knockout mice, where each ligand and receptor and their combinations were tested. PDGF-A ${ }^{-/-}$mice showed fewer PDGFRA-expressing progenitors than did either wild-type or PDGF- ${ }^{-/-}$mice (Betsholtz 1995; Lindahl et al. 1997b), implying that proliferation of oligodendrocyte progenitors strongly depend on PDGF-AA (Fruttiger et al. 1999). Accordingly, PDGFA ${ }^{-/-}$ mice developed with reduced numbers of oligodendrocytes, showing a myelination defect and tremor. These results also partly concord with PDGFRA $^{-/-}$mouse embryos that exhibited craniofacial abnormalities, spina bifida, and reduced numbers of oligodendrocyte progenitors (Soriano 1997; Sun et al. 2000). As was reported for O-2A progenitors (Bogler et al. 1990), both PDGF-AA and bFGF regulate oligodendrocyte proliferation and their differentiation into remyelinating oligodendrocytes after myelin damage (Murtie et al. 2005b). In fact, in wild type mice, endogenous FGF2 is increased between the first and second postnatal weeks at the peak of oligodendrogenesis (Murtie et al. 2005a).

Both PDGFRA $^{--}$and PDGFRB $^{--}$kill mice at midgestation or at birth, respectively. The PDGFRA $^{-/-}$phenocopy Patch $^{-/-}$mutant mice, lacking both PDGFRA and KIT genes, exhibit persistent truncus arteriosus, interrupted aortic arch, and decreased thymus volumes. This is caused by deficient progenitors of neural crest, but the phenotype was incomplete (Orr-Urtreger et al. 1992; Soriano 1997). Cranial and cardiac neural crest-specific conditional PDGFRA $^{-1}$ was created by crossing Cre recombinase under wnt1-promoter (Dorsky et al. 1998), expressing mice and PDGFRA ${ }^{\mathrm{FL} / \mathrm{FL}}$ mice (Tallquist and Soriano 2003), where the loss of PDGFRA leads to neonatal lethality due to aortic arch defects and cleft palate. Recently, the role of PDGFRB in cardiac $\mathrm{NC}$ was examined by using $\mathrm{PDGFRB}^{-/}$mice exhibiting ventricular septal defects (Richarte et al. 2007). Both receptors were found expressed in cardiac neural crest cells with slight differences in their expression patterns between E11-E14. Loss of both receptors rendered defective thymus formation as well as complete penetrance of persistent truncus arteriosus and retroesophageal origin of the right subclavian artery. $\mathrm{PDGFB}^{-/}$and $\mathrm{PDGFRB}^{-/-}$mice die of defects of early hematopoiesis and blood vessel formation. Renal defects arise due to defective development of pericytes and kidney podocytes (Leveen et al. 1994; Lindahl et al. 1997a; Hellstrom et al. 1999).

\section{PDGFR in embryonic neural and neural crest stem/ progenitor cells}

Ectomesenchymal cells are considered to be derived of neural crest of cranial region (Hall and Hörstadius, 1988; reviewed by Weston et al. 2004). Ectomesenchyme produces a variety of craniofacial skeletal and connective tissues, which are phenotypically different from neurogenic and melanogenic derivatives of the neural crest (Luo et al. 2003). The mesencephalic neural crest cells give rise to skeletal cells, the periocular mesenchyme, meninges, the pericytes of all facial and forebrain blood vessels, and also neurons and glia in the autonomic and the sensory nerves (Dupin et al. 2010). Embryonic ectomesenchyme-derived cells were shown to express PDGFRA (Mercola et al. 1990; Morrison-Graham et al. 1992; Orr-Urtreger et al. 1992; Schatteman et al. 1992; Soriano 1997).

In the amniote embryo, it has not been clear whether the neural crest-derived cephalic mesenchyme is derived from a common stem cell population. Recent data, however, point to the existence of a common pluripotent progenitor for chondrocytes, osteocytes, neurons, glia, melanocytes, and myofibrocytes, which persist at late embryonic and adult periods (Dupin et al. 2010). Moreover, neural crest-related progenitors have been isolated from the epidermal bulge of hair follicles and the dermal papilla of mammalian adult skin (Fernandes et al. 2004; Toma et al. 2005). These adult progenitors differentiate in vitro into both neural, and mesenchymal lineages, similarly to the multipotent cephalic neural crest cells in the early embryo period (Dupin et al. 2010). In the peripheral nervous system, sensory and sympathetic neurons originate from migrating neural crest cells. Furthermore, it was reported that Sox1-expressing neuroepithelium from the trunk region of E9.5 mice embryo produced mesenchymal stem cells through a PDGFRA-positive neural crest intermediate stage (Takashima et al. 2007). Moreover, the Sox 1 and PDGFRA-expressing cells gave rise to two subsets of cells distinguished by the expression of PDGFRB and A2B5. These neural crest-derived mesenchymal stem cells decrease during development and taken over by non-neural crest sources. By using neural crest- and mesenchymal celltracing, dental and thymic mesenchyme were composed of either neural crest- or mesoderm-derived cells, whereas half of the bone marrow mesenchyme was consisted of cells that were not derived from the neural crest or mesoderm. Colony 
formation was inhibited drastically by the addition of antiPDGFRB antibody, regardless of the tissue and its origin (Komada et al. 2012), suggesting that these mesenchymal stem cells carrying similar phenotype were derived from different sources.

\section{Expression of PDGFR in the embryonic neural crest and placodes}

Efforts were made to identify multipotent neural crest stem cells of cephalic origin that have capacities to differentiate into neuron, melanocytes, chondrocytes, and osteocytes by genetic fate mapping (Calloni et al. 2009). The cranial neural crest forms ectomesenchyme that is characterized by the ability to differentiate into numerous cell types normally associated with mesoderm, including muscle and bone (Le Lievre and Le Douarin 1975; Le Douarin et al. 1998). Cranial neural crest was shown to give rise to pericytes and smooth muscle cells to the cardiovascular system as well as the neurons and ganglia of sympathetic and parasympathetic nerves in the heart (Kirby et al. 1983). The remodeling of the pharyngeal arch arteries to separate the pulmonic and systemic circulation systems is also mediated by the cardiac neural crest cells (Brown and Baldwin 2006). These cells give rise to smooth muscle and pericytes in the arteries, and the neurons of cardiac innervation. Both PDGFRs are coexpressed in ectomesenchyme, although PDGFRA is expressed at a higher level (Tallquist and Soriano 2003; Weston et al. 2004).

Placodes are thickening of the embryonic head ectoderm that delaminate or invaginate to build nerve, ganglia and sensory organs. Neural crest is formed during neurulation, but placodes arise later in developing embryo. Recent genetic fate-mapping studies suggested that neural crest might have contributed to the formation of olfactory placodes as well as the otic placodes in rodents (Forni et al. 2011; Freyer et al. 2011). The neurogenic placodes generate a variety of mechanic and sensory structures and the pituitary. PDGFRB transcripts are expressed in the cranial ectoderm of chicken embryo and play important roles for the induction of ophthalmic trigeminal placode (McCabe and Bronner-Fraser 2008). Inhibiting PDGFR signals caused disappearance of the markers for trigeminal placode, Pax 3 and CD151, and abolished neuronal differentiation. Interestingly, at stage $8 \mathrm{em}-$ bryo, PDGFRA expression is found in the head and in somites, in contrast to PDGFRB that is localized in ectoderm and neural folds. At stage 10, PDGFRA is present in migrating neural crest and somites, but PDGFRB in ectoderm. PDGFRB is also present in the tips of stage 8 neural folds, but also found in neural crest and neural tube. The ligand PDGF-D is expressed in both cranial and trunk neural tube at stage 10-11, and the ligands for PDGFRA, PDGF-A is present in the midbrain ectoderm and PDGF-C in the presumptive mid-brain ectoderm at stage 8 (Fig. 2; McCabe and Bronner-Fraser 2008), suggesting distinct roles of these two receptors. Furthermore, FGF and/or PDGF are also necessary for activating the development of preplacodal ectoderm adjacent to the anterior neural plate during gastulation. Preplacodal cells are pluripotent that migrate and produce sensory structures of the head together with neural crest (Kwon et al. 2010).

\section{PDGF and adult-neural stem/progenitor cells}

The existence of adult human neural stem cells in the brain was confirmed and isolated essentially from the SVZ of the lateral ventricles, called SVZ astrocytes because of their morphology and marker expression (Lois and Alvarez-Buylla 1993). However, there are some reports that neural stem cells originate also from other types of cells, i.e., periventricular cells and ependymal cells (Johansson et al. 1999; Meletis et al. 2008; Chojnacki et al. 2009). Several groups have explored the plasticity of adults mesenchymal progenitors associated with perivascular niche (da Silva Meirelles et al. 2006; Bianco et al. 2008), which can be differentiated to several cell types, including neurons. Recently, Paul et al. demonstrated that mesenchymal stem cells with pericytes markers are present in perivascular areas, enabling to produce multi-lineage cells (Paul et al. 2012). It might be possible that neural crestderived pericytes in the vascular niche in the brain contribute to PDGFRB-expressing neuron, although no conclusive data is yet available.

For this reason, PDGFRB-expressing neural stem/progenitors might be derived from the perivascular niches, since PDGFRB is expressed by pericytes and the brain contains the highest density of capillary blood vessels. In fact, the development of neuronal cells is highly dependent on blood vessels, which occurs interdependently by mutual stimulation. This may indicate that PDGFRB contributes neuroepithelial-, neural crest- and mesenchymal-derived progenitors. It might be possible that PDGFRB plays more refined roles, such as the complex functions of cells in the nervous system and hematopoietic/immune system. The phenotypes of neural stem cells resemble astrocytes than neuron, and in development, radial glia has been considered to be the embryonic neural stem cells. Specific neuronal cells occurred later in the evolution, in concordance with the large differences of brain sizes and functions between amniotes and other vertebrates along with their varying needs for complex coordination of growth factors.

Primary cultures studied were derived from the SVZ of P1 and P28 mice, in which PDGFRB gene was deleted by nestin-promoter/enhancer-driven Cre recombinase (Ishii et al. 2008). The expression of PDGFRB in self-renewal and neuronal differentiation was indispensable for the neonatal neural stem/progenitors, but not in the P28 mice (Xu et al. 


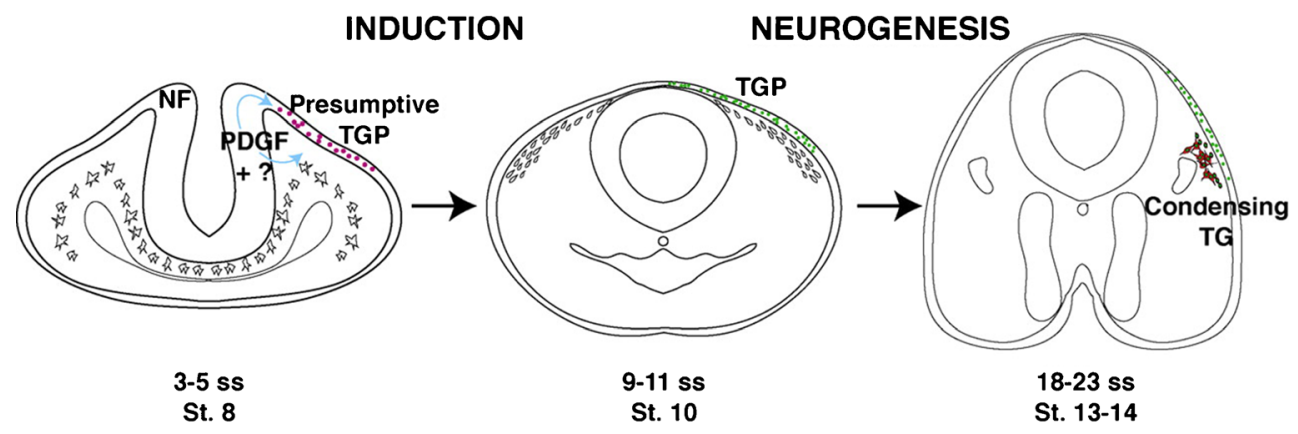

Fig. 2 Secreted PDGF ligand from the neural folds is necessary for opV trigeminal placode induction at stage 8 . By stage 10 , many opV trigeminal placode cells are specified (Pax3+ in green). By stage 1314 , opV trigeminal placode cells begin to delaminate and condense to

2013). Furthermore, BDNF and noggin, in addition to FGF2, were shown to be involved in PDGFRB-mediated regulation of neonatal neural stem/progenitors. PDGF receptors are rarely expressed on relatively quiescent GFAP-expressing neural stem cells (Doetsch et al. 1999), but present on nestin-positive and DCX-negative progenitor cells (Doetsch et al. 1999; Ishii et al. 2008). Periventricular PDGFRA-expressing cells do not seem to express GFAP (Chojnacki et al. 2011). PDGFR expressing progenitors can be expanded in neurospheres and differentiate into various types of nervous system cells, depending on availability of growth factors. These properties suggest that PDGFR-expressing progenitors might be the rapidly dividing, so-called C cells (Doetsch et al. 1999) in SVZ. PDGF and FGF act synergistically to maintain renewal of oligodendrocyte precursors, since their downstream signalings appear to reinforce mutual receptors (Ishii et al. 2008). This synergism was previously found to be utilized also in tumors (Nissen et al. 2007).

\section{Cell survival roles of PDGF in the nervous system}

All PDGF ligands and receptors were detected in the mammalian central nervous system (CNS; Sasahara et al. 1991; Yeh et al. 1991; Smits et al. 1991; Mudhar et al. 1993; Hutchins 1995; Reigstad et al. 2005). Specifically, PDGF-A, -B, -C, and their receptors also express in the peripheral nervous system, which originates from the neural crest (Eccleston et al. 1995; Peng et al. 2012). Increased expressions of PDGF and PDGFR were found in the lesioned area of CNS in experimental animal models for stroke, Huntington's and Parkinson's diseases (Iihara et al. 1994, 1996, 1997; Ballagi et al. 1994; Sjöborg et al. 1998; Ohno et al. 1999). A selective neuronal death in the CA1 subfield of hippocampus after transient forebrain ischemia was preceded by a rapid decrease of PDGF-B, which was prevented by pre-administered PDGF-B (Kaneko et al. 1998; Iihara et al. 1997). An altered expression of PDGF receptors has also been observed in association with various kinds of form regions of the op $\mathrm{V}$ trigeminal ganglion, expressing Pax3 (green), $\mathrm{Hu}$ and NF (red). TGP, opV trigeminal placode; TG, opV trigeminal ganglion. (Courtesy of Drs. McCabe and Bronner-Fraser, The Company of Biologists)

injuries in the nervous system (Ballagi et al. 1994; Hermanson et al. 1995), where the survival activity of PDGF signal was shown to play an important role. Similarly, PDGF-B and PDGF-C have a neuroprotective effect, as has been shown in several different animal models of neuronal injury, including ischemia (Sakata et al. 1998; Tang et al. 2010). Despite the overall similarity between PDGFRA and PDGFRB as for structural and downstream kinase targets, the role of these receptors differs considerably - partly due to the cell types expressing these receptors (Funa and Uramoto 2003). As for signaling, PDGFRB activation appears to induce a stronger anti-apoptotic response than PDGFRA by more strongly activating Akt, leading to survival of neurons upon injuries (Iihara et al. 1997; Funa and Ahgren 1997; Zhang et al. 2003).

\section{Roles of PDGF in the BBB function in the nervous system}

In the adult nervous system, functions exert as the integrated responses of neurovascular units that are comprised of neural and vascular cells. Thus, the pathogenesis of neurological diseases often resides in dysfunctions of neurovascular units (Zlokovic 2010). PDGF ligands and the receptors are expressed in both neural and vascular cells, and PDGF signaling is critically involved in the physiology and pathology of neurovascular units. Endothelial cells, pericytes, and astrocytes collaborate to maintain blood-brain barrier (BBB) functions, and the leakage of $\mathrm{BBB}$ in conjunction with stroke leads to life-threatening CNS edema. Two types of PDGFRs are differently involved in the regulation of BBB function. PDGF-B is expressed in vascular endothelial cells, and PDGFRB in pericytes and smooth muscle cells (PC/vSMCs). PDGF-B/PDGFRB axis is essential for the recruitment of PC/vSMCs in development (Hellstrom et al. 1999). The hypomorphic alleles of PDGF-B or PDGFRB gene decrease $\mathrm{PC} / \mathrm{vSMC}$ population in cerebral vasculature and result in BBB dysfunction in embryo and adult brains (Armulik et al. 
2010; Bell et al. 2010; Daneman et al. 2010). These BBB dysfunctions result in circulatory disturbances as well as progressive age-dependent vascular-mediated neurodegeneration (Bell et al. 2010). In conditional knockout mouse with postnatally induced PDGFRB gene inactivation, PC/vSMC population with regard to BBB function was not affected in the cerebral vascular system (Fig. 3; Shen et al. 2012). In this mutant, however, the PC/vSMC recruitment to the angiogenesis in the ischemic lesion of the brain is largely suppressed, where increased permeability of BBB is related to severe symptoms after stroke. PDGFRB-mediated recruitment of $\mathrm{PC} / \mathrm{vSMCs}$ is essential for the maturation of CNS vasculature in development and in post-ischemic adult angiogenesis (Krupinski et al. 1997).

On the other hand, tissue plasminogen activator (tPA) activates PDGF-CC in stroke brain. Consequently, activated PDGFRA on perivascular astrocytes increases BBB permeability, contrasting clearly to the role of PDGFRB ( $\mathrm{Su}$ et al. 2008). This is likely to be due to a difference in their targets-PDGFRA primary increases permeability but PDGFRB affects integrity of PC/vSMc. Accordingly, the inhibition of PDGFRA after ischemic stroke ameliorates both cerebrovascular permeability and hemorrhagic complications associated with late therapeutic administration of thrombolytic tPA. Two types of conditional PDGFRB knockout mouse, in which PDGFRB gene is inactivated in neurons, show large ischemic lesion to a similar extent at early time after ischemia, independent of blood-vessel associating PDGFRB (Shen et al. 2012). This indicates that endogenously
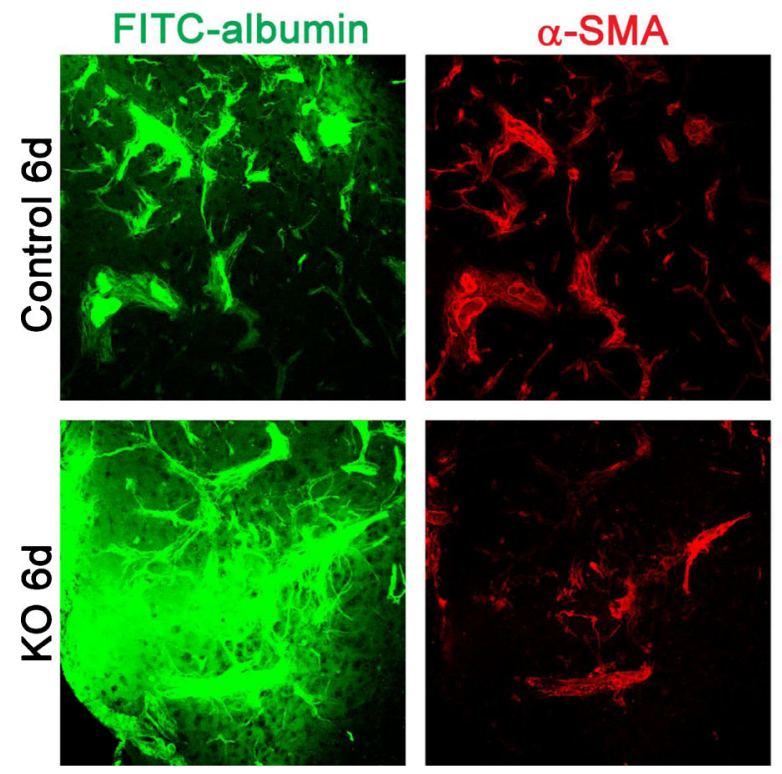

Fig. 3 Increased vascular permeability correlates with the loss of PC/vSMCs owing to PDGFR- $\beta$ deletion after cerebral ischemia. Confocal microscopic images of FITC-labeled albumin (green), $\alpha$-SMA (red), and PDGFR- $\beta$ (blue) stainings in the ischemic border in Floxed and Esr-KO mice at 6 days after MCAO. Scale expressed PDGFs protect nervous tissues, and that they can function independently of type of vasculature.

\section{PDGF signals protect neurons through multiple mechanisms}

Glutamate-NMDA receptor-mediated excitotoxicity and oxidative stress are two common mechanisms associating with most of neurodegenerative diseases. PDGF-BB inhibits NMDA-evoked currents and excitatory postsynaptic potentials that are mediated by NR2B-containing NMDA receptors in hippocampal neurons in vitro (Valenzuela et al. 1996; Lei et al. 1999; Beazely et al. 2009), and protects these neurons from glutamate- or NMDA-induced excitetoxicity (Tseng and Dichter 2005). A similar inhibition by PDGF-BB also occurs in rat CA1 pyramidal neurons in vitro (Valenzuela et al. 1996; Lei et al. 1999). Age-specific excitotoxicity in the immature brain is considered to be the pathogenesis underlying hypoxicischemic brain insults during the perinatal period (Whitelaw 2000). In fact, the expression of PDGF-B and PDGFRB is upregulated in rodent neonatal and mature brain (Smits et al. 1991; Sasahara et al. 1992, 1995, 1998), where the level of PDGF-B is inversely correlated with NMDA excitotoxicity, and is functionally implicated in the excitotoxicity in PDGFBB peptide infusion and expression-inhibition studies (Egawa-Tsuzuki et al. 2004).

Moreover, NMDA excitotoxicity was increased in neural cell-specific conditional knockout mouse of PDGFRB in adult
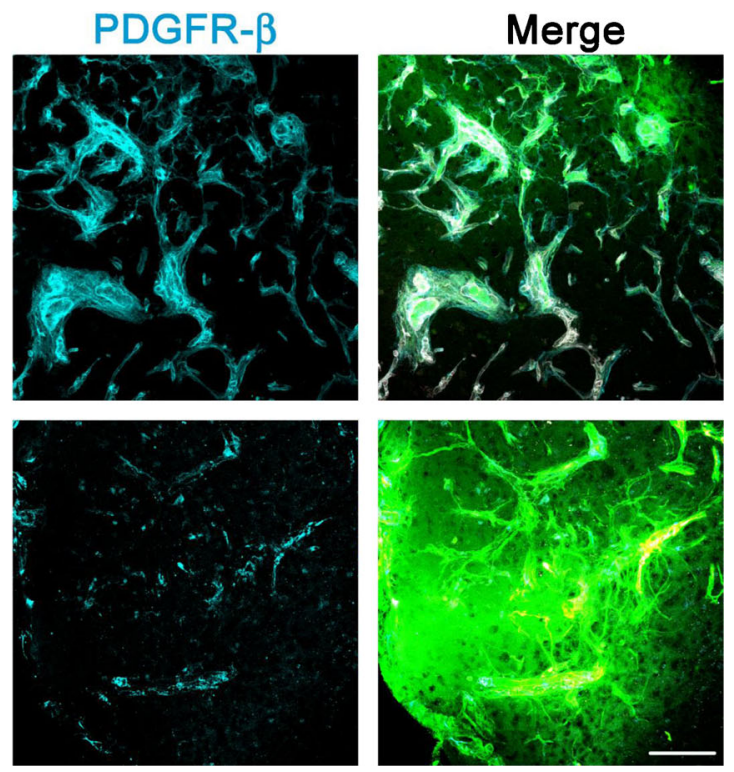

bars $=100 \mu \mathrm{m} . \alpha$-SMA, $\alpha$-smooth muscle actin; FITC, fluorescein isothiocyanate; MCAO, middle cerebral artery occlusion; $\mathrm{PC} / \mathrm{vSMC}$, pericyte/vascular smooth muscle cell; PDGFR, platelet-derived growth factor receptor. (Courtesy of Journal of Cerebral Blood Flow and Metabolism) 
period (Ishii et al. 2006). Through both in vivo and in vitro studies, the PDGF-BB/PDGFRB axis is assumed to be an endogenous modulator of neuronal excitability. However, the mechanism to suppress excitotoxicity seems not merely to be due to direct inhibition of the NMDA receptor, since the maximum effects of PDGF-mediated suppression on the NMDA receptor reaches 40 min (Valenzuela et al. 1996), in contrast to the neuroprotective effects that take $24 \mathrm{~h}$ to reach maximum (Tseng and Dichter 2005).

This mechanism might be related to other signaling pathways. Induction of downstream prosurvival genes including GSK3 $\beta$ and the phosphatidylinositol 3-kinase K (PI3-K)/Akt is important for the anti-excitotoxicity effects of PDGF, besides direct inhibition of NMDA receptor (Peng et al. 2008; Tang et al. 2010). Activation of PI3-K/Akt and MAP kinase is also involved in PDGF-mediated neuroprotection from $\mathrm{H}_{2} \mathrm{O}_{2}-$ mediated oxidative stress in vitro (Zheng et al. 2010). ROS accumulated in cerebral lesions has been shown to mediate the tissue damage in NMDA-induced cerebral injury (Küçükkaya et al. 1996; Bolaños et al. 1997). PDGF attenuates neuronal death due by glucose-deprivation and oxidative injury in hippocampal cultures by increasing activity of antioxidant enzymes (Cheng and Mattson 1995). Pretreatment with PDGF-BB, but not PDGF-AA, can counteract 6-OHDAinduced degeneration of mesencephalic DA neurons in culture (Pietz et al. 1996). Similarly, PDGF-BB, but not PDGF-AA, substantially prevented hippocampal neuronal cell death after transient forebrain ischemia in vivo (Iihara et al. 1997). PDGF-BB rescues primary neurons from $\mathrm{H}_{2} \mathrm{O}_{2}$ induced oxidative stress more potently than PDGF-AA, and deletion of PDGFRB substantially ameliorated the effect of PDGF-BB (Zheng et al. 2010). The anti-oxidative effect of PI3-K/Akt may be one of the mechanisms to prevent excitotoxic neuronal death. Thus, neuroprotective effects of PDGF should be considered in a broader time period from an increased neuronal cell survival early after insult, to later tissue responses including neurogenesis, angiogenesis, and gliosis, which can be important targets of PDGF (Mohapel et al. 2005; Shen et al. 2012).

Additional neuroprotective mechanisms downstream of PDGFRB have been reported, i.e., the increased expression of glutamate transporters on neurons (Figiel et al. 2003) and the involvement of transient receptor potential (TRP) $\mathrm{C} 1$ and TRPC6 channels (Yao et al. 2009). Endogenously and exogenously given PDGF-CC rescues neurons from apoptosis in brain and retina subjected to different injuries, and the rescue is mediated by PDGFRA and PDGFRB (Tang et al. 2010). Thus, depending on the type of noxious stimuli or locus of injury, the involved PDGF ligand and receptor may be different. In addition to neurons subjected to ischemia, the neuroprotective role of PDGF is relatively well characterized in dopaminergic neurons, both in vivo and in vitro (Nikkhah et al. 1993; Mohapel et al. 2005; Funa and Ahgren 1997; Tang et al. 2010). PDGF replacement therapy might become applicable to treat stroke, neurodegenerative diseases, and diseases involving dopaminergic neurons such as Parkinson's. Small molecule ligands for serotonin-7 receptor suppress excitotoxicity via induction and activation of PDGFRB (Vasefi et al. 2013). For a future neuroprotective strategy, these BBB-permeable small molecules can hopefully become tools to enforce endogenous growth factor signals in the CNS in order to prevent tissue insult.

\section{Role of PDGF in synaptic functions}

PDGFRB is localized in pre- and post-synaptic structures of the adult mouse hippocampus (Shioda et al. 2012), regulating synaptic plasticity and function, and is intimately implicated as a neuromodulator in different neurological activities. A brief application of PDGF-BB produces a long-lasting inhibition of NMDA-evoked currents and excitatory postsynaptic potentials in rat CA1 pyramidal neurons in cell culture and in hippocampal brain slice (Valenzuela et al. 1996). PDGFRB activation decreases NMDA-evoked current in cultured neurons through a feed-forward inhibitory mechanism, and the inhibitory effects are dependent on PDGF-induced release of intracellular calcium (Valenzuela et al. 1996; Lei et al. 1999). Along this line, PDGF-BB treatment inhibits NR2B-containing NMDA receptor currents in CA1 hippocampal neurons, and enhances LTD in an NR2B subunit-dependent manner in hippocampal brain slice (Beazely et al. 2009). The activation of PDGFR $\beta$ receptor occurs through the transactivation by $\mathrm{D} 2$-like dopamine receptor that may underlie dopamine receptor-mediated inactivation of NMDA receptor in acutely isolated CA1 hippocampal neurons and hippocampal brain slice, as well as in prefrontal neurons (Kotecha et al. 2002; Beazely et al. 2006).

On the other hand, PDGF-BB suppressed AMPA-mediated excitatory postsynaptic currents evoked by electrical stimulation of the tractus solitarius in mouse nTS second-order neurons (Ohi et al. 2007). This suppressive effect of PDGF-BB is abolished by PDGFRB gene knockout. The single activation of NMDA receptors is not sufficient for the efficient $\mathrm{Ca}^{2+}$ influx to neuron, but the AMPA receptor-mediated depolarization is a prerequisite for this process (Herron et al. 1986). In the nTS tract, PDGF-B/PDGFRB effectively suppresses glutamatergic excitatory signaling through coordinate suppression of AMPA and NMDA receptors, which has important functional implications in acute hypoxic ventilatory response and subsequent functional adaptations and synaptic plasticity phenomena (Gozal et al. 2000; Zhang et al. 2003). Pharmacological inhibition or diminished expression of PDGFRB abolishes the typical ventilatory decline (= ventilatory roll-off) that characteristically occurs with ongoing hypoxia. Similarly, this ventilatory roll-off disappears in conditional knockout of PDGFRB (Tsunekawa et al. 2009). 
In the hippocampus, PDGFRB colocalizes with both presynaptic synaptophysin and postsynaptic density-95 (PSD-95). Consistent with these observations, hippocampal long-term potentiation (LTP) and hippocampus-dependent memory formation were impaired by depletion of PDGFRB from neural cells in embryonic period (Shioda et al. 2012). In these mice, post-synapse-related proteins, including PSD95 and phosphorylated Akt and ERK, are decreased in hippocampal CA1 pyramidal neurons. In a different report, PDGF induces Arc/Arg3.1 gene expression via the induction of immediate early gene Egr-1 in hippocampal neurons, and enhances LTP in CA pyramidal neurons in hippocampal slice (Peng et al. 2010). In stimulated neurons, translation of the dendritically localized mRNA, Arc, is required for consolidation of LTP and stabilization of nascent polymerized actin (Bramham 2008). $\mathrm{Na}^{+} / \mathrm{H}^{+}$exchanger regulatory factors (NHERFs) are scaffold proteins distributed in dendritic spines and in axon terminals of hippocampal pyramidal neurons (Paquet et al. 2006). PDGFRB specifically binds to NHERFs, independently of receptor activation (Demoulin et al. 2003), and crucially contributes to the actin reorganization (James et al. 2004; Theisen et al. 2007). Accordingly, PDGFRB may contribute to dendritic spine morphogenesis or plasticity, an event crucially regulated by the postsynaptic actin cytoskeleton (Svitkina et al. 2010), through PDGFRBactivation in both dependent and independent manners.

PDGF exerts neurotrophic effects on both $\gamma$-aminobutyric acid(GABA)ergic and dopaminergic neurons (Smits et al. 1991, 1993; Othberg et al. 1995). Aberrant development of GABAergic circuits has been implicated in various neurodevelopmental and psychiatric disorders such as schizophrenia (Lewis et al. 2005), autism (Belmonte et al. 2004; Dani et al. 2005) and Tourette's syndrome (Kalanithi et al. 2005). As deduced from these, nestin-Cre mediated PDGFRB gene knockout in neural cells in embryonic periods reduces the number of parvalbumin (calcium-binding protein)-positive (i.e., putatively GABAergic) neurons in the amygdala, hippocampus, and medial prefrontal cortex of adult mouse brain (Nguyen et al. 2011). These mice show behavioral and electrophysiological abnormalities characteristic to autism or schizophrenia, including defective social behavior, spatial memory and sensory-evoked gamma oscillations. Genetic linkage analyses have shown PDGFRB to be located on chromosome 5q31-q32 (Kalanithi et al. 2005), which contains susceptibility genes for schizophrenia (Silverman et al. 1996; Shaw et al. 1998; Gurling et al. 2001; DeLisi et al. 2002; Devlin et al. 2002; Sklar et al. 2004; Herzberg et al. 2006). Three single nucleotide polymorphisms and 2 haplotypes of PDGFRB are associated with schizophrenia (Kim et al. 2008), and the serum levels of PDGF-BB are high in autistic boys (Kajizuka et al. 2010). After all, PDGF/PDGFR signal may have etiological implications in neurodevelopmental and psychiatric disorders.

\section{Pharmacological use of PDGF-signal modifiers}

Various PDGFR tyrosine kinase inhibitors (TKIs), mostly ATP competitors, have been found to be small-molecule inhibitors. Examples of such molecules that have been investigated are the indole-2 ones (SU6668), the quinoxalines and their derivatives, 3-(indol-3-yl)quinoxalin-2-ones, the tyrophostines (AG1295, RG50864), the pyridylpyrimidines (STI-571), the quinolines and quinazolines (CT52923), the indoles, the imidazoles (CP-868596, TAK593), and the pyrazoles (ABT-869) (see Aoki et al. 2007). These drugs are mostly applied in therapies of cancer and cardiovascular diseases, but also in some inflammatory conditions and fibrosis. Several TKIs, especially those against EGFR and VEGFR, have been used against aggressive brain tumors, e.g. glioblastoma multiforme. However, the tumor cells treated by these inhibitors usually develop resistance.

Increased sensitivity to the PDGFR inhibitor STI571 in chemoresistant glioma cells is associated with enhanced PDGF-mediated signaling and STI571-induced Akt inactivation (Servidei et al. 2006). In fact, de-repression of PDGFRB was found to promote resistance to EGFR TKIs in glioma cells (Akhavan et al. 2013). For this reason, combined therapy with the PDGFR TKI might provide benefits. The VEGFR inhibitor sunitinib decreased phosphorylation of Akt and mTOR (Saito et al. 2012). PDGFR also induces strong downstream pathways, such as PI3-K, Akt, and mTOR, hence certain PDGF inhibitors might act in a similar fashion. Several multi-targeted receptor TKIs with activity against various intracellular kinases with anti-angiogenic mechanisms have been used with better results in neuroblastoma (Dai et al. 2008; Nilsson et al. 2010). Many of these TKIs have shown better clinical activity in combination with chemotherapy, as well as with inhibitors of mTOR, angiopoietin/TIE2, integrin, Notch, Wnt $/ \beta$-catenin and vasculogenesis pathways. Those signaling molecules are shown to be important for maintenance of quiescent cancer stem cells, which could be targeted by their inhibitors in combination with the TKI ( $\mathrm{Li}$ and Bhatia 2011).

The use of kinase inhibitors in other diseases than tumors may need higher specificity for the target kinase. It is also possible to block one or a few intercellular kinases downstream of the PDGFR kinase, when the major disease symptoms depend on such kinases. For example, when PI3-K is to be targeted, the inhibitors wortmannin and LY294002 can be effective. By doing so, the other receptor kinases also activating PI3-K, such as VEGFR, IGFR, and Her2/Her3, can be inhibited (Dell et al. 2006). In the case of disruption of the blood-brain barrier, involving activation of PDGFRA, the impairment was reversed by the p38 MAPK inhibitor, SB203580 (Ma et al. 2011).

Several methods are under development to counteract, e.g., insufficient production of PDGF, being a major mechanism in 
disease. Examples include degeneration of neurons and oligodendrocytes. Replacement therapy has been suggested, using in vitro differentiated neuroprogenitors or iPS-derived cells cultured with PDGF and/or other factors (Johnson et al. 2010). In addition, recent technical development has enabled controlled delivery of PDGF-BB into the infarcted myocardium of mouse by the use of PDGF-BB-bound self-assembling nanofibers (Hsieh et al. 2006). These types of methods could be used to control the differentiation of induced pluripotent stem (iPS) cells in order to eliminate a risk to induce tumors from transplanted cells (Brederlau et al. 2006). For iPS cell therapy, it is also possible to replace a fragment of genes not only to repair mutations, but also conditionally induce certain gene expression by targeted genomic integration using zink-finger nucleases (Gantz et al. 2012). This can be applied for in vitro selection of certain types of differentiated iPS by inserting reporter genes downstream of PDGFRA or PDGFRB promotor (Funa and Uramoto 2003), depending on differentiation of the desired cell type (Wang et al. 2012).

In summary, PDGFs and/or PDGFRs can be expressed in neural progenitors, neurons, astrocytes, oligodendrocytes, and vascular cells (Fig. 1). PDGF exerts diverse but specific functions in the nervous system, covering neurogenesis, cell survival, synaptogenesis, modulation of ligand-gated ion channels, and development of specific types of neurons. Future development of specific drugs will target PDGFR, as well as a controlled delivery of PDGF, in the diseased tissues, and/or be combined with iPS-based replacement therapies. These new therapies would promise to ameliorate the prognosis of patients suffering from these malignant nervous system tumors as well as neurodegenerative diseases. These major disorders still lack efficient therapies.

\begin{abstract}
Acknowledgment This work was supported by grants from the Swedish Science Council, the Swedish Cancer Society, the Swedish Childhood Cancer Foundation, the IngaBritt and Arne Lundberg Research Foundation, the Västra Götaland Region County Council (ALF), Wilhelm och Martina Lundgren Foundation, Åhlen's Foundation, Adlerbertska Research Foundation, Grants-in-Aid for Scientific Research from the Ministry of Education, Culture, Sports, Science and Technology of Japan, and Core Research for Evolutional Science and Technology, Japan Science and Technology Agency (CREST, JST; grants 23590444, 20590381, 20390108). Figure 1 was reproduced from the article by McCabe, KL and Bronner-Fraser, M, 2008 (doi:10.1242/dev.017954), as listed in the references, with permission by the authors and the publisher (Development: dev.biologists.org.)
\end{abstract}

Disclosure of conflict of interest The authors state no potential conflicts of interest involved in preparing this article.

Open Access This article is distributed under the terms of the Creative Commons Attribution License which permits any use, distribution, and reproduction in any medium, provided the original author(s) and the source are credited.

\section{References}

Ahluwalia MS, Patel M, Peereboom DM (2011) Role of tyrosine kinase inhibitors in the management of high-grade gliomas. Expert Rev Anticancer Ther 11:1739-1748

Akhavan D, Pourzia AL, Nourian AA, Williams KJ, Nathanson D, Babic I, Villa GR, Tanaka K, Nael A, Yang H, Dang J, Vinters HV, Yong WH, Flagg M, Tamanoi F, Sasayama T, James CD, Kornblum HI, Cloughesy TF, Cavenee WK, Bensinger SJ, Mischel PS (2013) De-repression of PDGFRB transcription promotes acquired resistance to EGFR tyrosine kinase inhibitors in glioblastoma patients. Cancer Discov 3:534-547

Alea OA, Czapla MA, Lasky JA, Simakajornboon N, Gozal E, Gozal D (2000) PDGF-beta receptor expression and ventilatory acclimatization to hypoxia in the rat. Am J Physiol Regul Integr Comp Physiol 279:R1625-R1633

Andrae J, Gallini R, Betsholtz C (2008) Role of platelet-derived growth factors in physiology and medicine. Genes Dev 22:1276-1312

Aoki K, Obata T, Yamazaki Y, Mori Y, Hirokawa H, Koseki J, Hattori T, Niitsu K, Takeda S, Aburada M, Miyamoto K (2007) Potent platelet-derived growth factor-beta receptor (PDGF-betaR) inhibitors: synthesis and structure-activity relationships of 7[3-(cyclohexylmethyl)ureido]-3-\{1-methyl-1H-pyrrolo[2,3-b]pyri din-3-yl quinoxal in-2 $\left({ }^{1} \mathrm{H}\right)$-one derivatives. Chem Pharm Bull (Tokyo) 55:255-267

Armulik A, Genove G, Mae M, Nisancioglu MH, Wallgard E, Niaudet C, He L, Norlin J, Lindblom P, Strittmatter K, Johansson BR, Betsholtz C (2010) Pericytes regulate the blood-brain barrier. Nature 468:557-561

Ball SG, Shuttleworth CA, Kielty CM (2007) Mesenchymal stem cells and neovascularization: role of platelet-derived growth factor receptors. J Cell Mol Med 11:1012-1030

Ballagi AE, Odin P, Othberg-Cederström A, Smits A, Duan WM, Lindvall O, Funa K (1994) Platelet-derived growth factor receptor expression after neural grafting in a rat model of Parkinson's disease. Cell Transplant 3:453-460, 11:1012-1030

Beazely MA, Tong A, Wei WL, Van Tol H, Sidhu B, MacDonald JF (2006) D2-class dopamine receptor inhibition of NMDA currents in prefrontal cortical neurons is platelet-derived growth factor receptor-dependent. J Neurochem 98:1657-1663

Beazely M, Lim A, Li H, Trepanier C, Chen X, Sidhu B, Macdonald JF (2009) Platelet-derived growth factor selectively inhibits NR2Bcontaining N-methyl-D-aspartate receptors in CA1 hippocampal neurons. J Biol Chem 284:8054-8063

Bell RD, Winkler EA, Sagare AP, Singh I, LaRue B, Deane R, Zlokovic BV (2010) Pericytes control key neurovascular functions and neuronal phenotype in the adult brain and during brain aging. Neuron 68:409-427

Belmonte MK, Cook EH Jr, Anderson GM, Rubenstein JL, Greenough WT, Beckel-Mitchen A, Courchesne E, Boulanger LM, Powell SB, Levitt PR, Perry EK, Jiang YH, DeLorey TM, Tierney E (2004) Autism as a disorder of neural information processing: directions for research and targets for therapy. Mol Psychiatry 9:646-663

Bergsten E, Uutela M, Li X, Pietras K, Ostman A, Heldin CH, Alitalo K, Eriksson U (2001) PDGF-D is a specific, protease-activated ligand for the PDGF beta-receptor. Nat Cell Biol 3:512-516

Betsholtz C (1995) Role of platelet-derived growth factors in mouse development. Int J Dev Biol 39:817-825

Bianco P, Robey PG, Simmons PJ (2008) Mesenchymal stem cells: revisiting history, concepts, and assays. Cell Stem Cell 2:313-319

Bogler O, Wren D, Barnett SC, Land H, Noble M (1990) Cooperation between two growth factors promotes extended self-renewal and inhibits differentiation of oligodendrocyte-type-2 astrocyte (O2A) progenitor cells. Proc Natl Acad Sci U S A 87:6368-6372 
Bolaños JP, Almeida A, Stewart V, Peuchen S, Land JM, Clark JB, Heales SJ (1997) Nitric oxide-mediated mitochondrial damage in the brain: mechanisms and implications for neurodegenerative diseases. J Neurochem 68:2227-2240

Bramham CR (2008) Local protein synthesis, actin dynamics, and LTP consolidation. Curr Opin Neurobiol 18:524-531

Brederlau A, Correia AS, Anisimov SV, Elmi M, Paul G, Roybon L, Morizane A, Bergquist F, Riebe I, Nannmark U, Carta M, Hanse E, Takahashi J, Sasai Y, Funa K, Brundin P, Eriksson PS, Li JY (2006) Transplantation of human embryonic stem cell-derived cells to a rat model of Parkinson's disease: effect of in vitro differentiation on graft survival and teratoma formation. Stem Cells 24:1433-1440

Brown CB, Baldwin HS (2006) Neural crest contribution to the cardiovascular system. Adv Exp Med Biol 589:134-154

Calloni GW, Le Douarin NM, Dupin E (2009) High frequency of cephalic neural crest cells shows coexistence of neurogenic, melanogenic, and osteogenic differentiation capacities. Proc Natl Acad Sci U S A 106:8947-8952

Cheng B, Mattson MP (1995) PDGFs protect hippocampal neurons against energy deprivation and oxidative injury: evidence for induction of antioxidant pathways. J Neurosci 15:7095-7104

Chojnacki A, Weiss S (2004) Isolation of a novel platelet-derived growth factor-responsive precursor from the embryonic ventral forebrain. J Neurosci 24:10888-10899

Chojnacki A, Kelly JJ, Hader W, Weiss S (2008) Distinctions between fetal and adult human platelet-derived growth factor-responsive neural precursors. Ann Neurol 64:127-142

Chojnacki AK, Mak GK, Weiss S (2009) Identity crisis for adult periventricular neural stem cells: subventricular zone astrocytes, ependymal cells or both? Nat Rev Neurosci 10:153-163

Chojnacki A, Mak G, Weiss S (2011) PDGFRalpha expression distinguishes GFAP-expressing neural stem cells from PDGFresponsive neural precursors in the adult periventricular area. $\mathrm{J}$ Neurosci 31:9503-9512

da Silva Meirelles L, Chagastelles PC, Nardi NB (2006) Mesenchymal stem cells reside in virtually all post-natal organs and tissues. J Cell Sci 119:2204-2213

Dai Y, Hartandi K, Soni NB, Pease LJ, Reuter DR, Olson AM, Osterling DJ, Doktor SZ, Albert DH, Bouska JJ, Glaser KB, Marcotte PA, Stewart KD, Davidsen SK, Michaelides MR (2008) Identification of aminopyrazolopyridine ureas as potent VEGFR/PDGFR multitargeted kinase inhibitors. Bioorg Med Chem Lett 18:386-390

Daneman R, Zhou L, Kebede AA, Barres BA (2010) Pericytes are required for blood-brain barrier integrity during embryogenesis. Nature 468:562-566

Dani VS, Chang Q, Maffei A, Turrigiano GG, Jaenisch R, Nelson SB (2005) Reduced cortical activity due to a shift in the balance between excitation and inhibition in a mouse model of Rett syndrome. Proc Natl Acad Sci U S A 102:12560-12565

DeLisi LE, Mesen A, Rodriguez C, Bertheau A, LaPrade B, Llach M, Riondet S, Razi K, Relja M, Byerley W, Sherrington R (2002) Genome-wide scan for linkage to schizophrenia in a Spanishorigin cohort from CostaRica. Am J Med Genet 114(5):497-508

Dell S, Peters S, Muther P, Kociok N, Joussen AM (2006) The role of PDGF receptor inhibitors and PI3-kinase signaling in the pathogenesis of corneal neovascularization. Investig Ophthalmol Vis Sci 47:1928-1937

Demoulin JB, Seo JK, Ekman S, Grapengiesser E, Hellman U, Rönnstrand L, Heldin CH (2003) Ligand-induced recruitment of $\mathrm{Na}+\mathrm{H}+-$ exchanger regulatory factor to the PDGF (platelet-derived growth factor) receptor regulates actin cytoskeleton reorganization by PDGF. Biochem J 376:505-510

Devlin B, Bacanu SA, Roeder K, Reimherr F, Wender P, Galke B, Novasad D, Chu A, TCuenco K, Tiobek S, Otto C, Byerley W (2002) Genome-wide multi point linkage analyses of multiplex schizophrenia pedigrees from the oceanic nation of Palau. Mol Psychiatry 7(7):689-694

Doetsch F, Caille I, Lim DA, Garcia-Verdugo JM, Alvarez-Buylla A (1999) Subventricular zone astrocytes are neural stem cells in the adult mammalian brain. Cell 97:703-716

Dorsky RI, Moon RT, Raible DW (1998) Control of neural crest cell fate by the Wnt signalling pathway. Nature 396:370-373

Dupin E, Calloni GW, Le Douarin NM (2010) The cephalic neural crest of amniote vertebrates is composed of a large majority of precursors endowed with neural, melanocytic, chondrogenic and osteogenic potentialities. Cell Cycle 9:238-249

Eccleston PA, Funa K, Heldin CH (1995) Expression of PDGF and PDGR alpha- and beta-receptors in the peripheral nervous system: an analysis of sciatic nerve and dorsal root ganglia. Dev Biol 155:459-470

Egawa-Tsuzuki T, Ohno M, Tanaka N, Takeuchi Y, Uramoto H, Faigle R, Funa K, Ishii Y, Sasahara M (2004) The PDGF B-chain is involved in the ontogenic susceptibility of the developing rat brain to NMDA toxicity. Exp Neurol 186:89-98

Fernandes KJ, McKenzie IA, Mill P, Smith KM, Akhavan M, BarnabeHeider F, Biernaskie J, Junek A, Kobayashi NR, Toma JG, Kaplan DR, Labosky PA, Rafuse V, Hui CC, Miller FD (2004) A dermal niche for multipotent adult skin-derived precursor cells. Nat Cell Biol 6:1082-1093

Figiel M, Maucher T, Rozyczka J, Bayatti N, Engele J (2003) Regulation of glial glutamate transporter expression by growth factors. Exp Neurol 183:124-135

Forni PE, Taylor-Burds C, Melvin VS, Williams T, Wray S (2011) Neural crest and ectodermal cells intermix in the nasal placode to give rise to GnRH-1 neurons, sensory neurons, and olfactory ensheathing cells. J Neurosci 31:6915-6927

Fredriksson L, Li H, Eriksson U (2004) The PDGF family: four gene products form five dimeric isoforms. Cytokine Growth Factor Rev 15:197-204

Freyer L, Aggarwal V, Morrow BE (2011) Dual embryonic origin of the mammalian otic vesicle forming the inner ear. Development 138:5403-5414

Fruttiger M, Karlsson L, Hall AC, Abramsson A, Calver AR, Bostrom $\mathrm{H}$, Willetts K, Bertold CH, Heath JK, Betsholtz C, Richardson WD (1999) Defective oligodendrocyte development and severe hypomyelination in PDGF-A knockout mice. Development 126:457-467

Funa K, Ahgren A (1997) Characterization of platelet-derived growth factor (PDGF) action on a mouse neuroblastoma cell line, NB41, by introduction of an antisense PDGF beta-receptor RNA. Cell Growth Differ 8:861-869

Funa K, Uramoto H (2003) Regulatory mechanisms for the expression and activity of platelet-derived growth factor receptor. Acta Biochim Pol 50:647-658

Gantz JA, Palpant NJ, Welikson RE, Hauschka SD, Murry CE, Laflamme MA (2012) Targeted genomic integration of a selectable floxed dual fluorescence reporter in human embryonic stem cells. PLoS One 7:e46971

Goldman SA, Nedergaard M, Windrem MS (2012) Glial progenitor cell-based treatment and modeling of neurological disease. Science 338:491-495

Gozal D, Simakajornboon N, Czapla MA, Xue YD, Gozal E, Vlasic V, Lasky JA, Liu JY (2000) Brainstem activation of platelet-derived growth factor-beta receptor modulates the late phase of the hypoxic ventilatory response. J Neurochem 74:310-319

Gurling HM, Kalsi G, Brynjolfson J, Sigmundsson T, Sherrington R, Mankoo BS, Read T, Murphy P, Blaveri E, McQuillin A, Petursson H, Curtis D (2001) Genomewide genetic linkage analysis confirms the presence of susceptibility loci for schizophrenia, on chromosomes 1q32.2, 5q33.2, and 8p21-22 and provides support for linkage to schizophrenia, on chromosomes 11q23.3-24 and 20q12.1-11.23. Am J Hum Genet 68:661-673 
Hammacher A, Hellman U, Johnsson A, Östman A, Gunnarson K, Westermark B, Wasteson A, Heldin C-H (1988) A major part of platelet-derived growth factor purified from human platelets is a heterodimer of one A and one B chain. J Biol Chem 263:1649316498

Heldin CH (2012) Autocrine PDGF stimulation in malignancies. Ups J Med Sci 117:83-91

Heldin CH, Westermark B (1999) Mechanism of action and in vivo role of platelet-derived growth factor. Physiol Rev 79:1283-1316

Heldin CH, Ostman A, Ronnstrand L (1998) Signal transduction via platelet-derived growth factor receptors. Biochim Biophys Acta 1378:F79-F113

Hellstrom M, Kalen M, Lindahl P, Abramsson A, Betsholtz C (1999) Role of PDGF-B and PDGFR-beta in recruitment of vascular smooth muscle cells and pericytes during embryonic blood vessel formation in the mouse. Development 126:30473055

Hermanson M, Olsson T, Westermark B, Funa K (1995) PDGF and its receptors following facial nerve axotomy in rats: expression in neurons and surrounding glia. Exp Brain Res 102:415-422

Herron CE, Lester RA, Coan EJ, Collingridge GL (1986) Frequencydependent involvement of NMDA receptors in the hippocampus: a novel synaptic mechanism. Nature 322:265-268

Herzberg I, Jasinska A, García J, Jawaheer D, Service S, Kremeyer B, Duque C, Parra MV, Vega J, Ortiz D, Carvajal L, Polanco G, Restrepo GJ, López C, Palacio C, Levinson M, Aldana I, Mathews C, Davanzo P, Molina J, Fournier E, Bejarano J, Ramírez M, Ortiz CA, Araya X, Sabatti C, Reus V, Macaya G, Bedoya G, Ospina J, Freimer N, Ruiz-Linares A (2006) Convergent linkage evidence from two Latin-American population isolates supports the presence of a susceptibility locus for bipolar disorder in 5q31-34. Hum Mol Genet 15:3146-3153

Hsieh PC, Davis ME, Gannon J, MacGillivray C, Lee RT (2006) Controlled delivery of PDGF-BB for myocardial protection using injectable self-assembling peptide nanofibers. J Clin Invest 116:237-248

Hutchins JB (1995) Platelet-derived growth factor receptors of mouse central nervous system cells in vitro. J Comp Neurol 360:59-80

Iihara K, Sasahara M, Hashimoto N, Uemura Y, Kikuchi H, Hazama F (1994) Ischemia induces the expression of the platelet-derived growth factor-B chain in neurons and brain macrophages in vivo. J Cereb Blood Flow Metab 14:818-824

Iihara K, Sasahara M, Hashimoto N, Hazama F (1996) Induction of platelet-derived growth factor beta-receptor in focal ischemia of rat brain. J Cereb Blood Flow Metab 16:941-949

Iihara K, Hashimoto N, Tsukahara T, Sakata M, Yanamoto H, Taniguchi T (1997) Platelet-derived growth factor-BB, but not $\mathrm{AA}$, prevents delayed neuronal death after forebrain ischemia in rats. J Cereb Blood Flow Metab 17:1097-1106

Ishii Y, Oya T, Zheng L, Gao Z, Kawaguchi M, Sabit H, Matsushima T, Tokunaga A, Ishizawa S, Hori E, Nabeshima Y, Sasaoka T, Fujimori T, Mori H, Sasahara M (2006) Mouse brains deficient in neuronal PDGF receptor-beta develop normally but are vulnerable to injury. J Neurochem 98:588-600

Ishii Y, Matsumoto Y, Watanabe R, Elmi M, Fujimori T, Nissen J, Cao Y, Nabeshima Y, Sasahara M, Funa K (2008) Characterization of neuroprogenitor cells expressing the PDGF beta-receptor within the subventricular zone of postnatal mice. Mol Cell Neurosci 37:507-518

James MF, Beauchamp RL, Manchanda N, Kazlauskas A, Ramesh V (2004) A NHERF binding site links the betaPDGFR to the cytoskeleton and regulates cell spreading and migration. J Cell Sci 117:2951-2961

Johansson CB, Momma S, Clarke DL, Risling M, Lendahl U, Frisen J (1999) Identification of a neural stem cell in the adult mammalian central nervous system. Cell 96:25-34
Johnson PJ, Tatara A, Shiu A, Sakiyama-Elbert SE (2010) Controlled release of neurotrophin-3 and platelet-derived growth factor from fibrin scaffolds containing neural progenitor cells enhances survival and differentiation into neurons in a subacute model of SCI. Cell Transplant 19:89-101

Kajizuka M, Miyachi T, Matsuzaki H, Iwata K, Shinmura C, Suzuki K, Suda S, Tsuchiya KJ, Matsumoto K, Iwata Y, Nakamura K, Tsujii M, Sugiyama T, Takei N, Mori N (2010) Serum levels of plateletderived growth factor $\mathrm{BB}$ homodimers are increased in male children with autism. Prog Neuropsychopharmacol Biol Psychiatry 34:154 158

Kalanithi PS, Zheng W, Kataoka Y, DiFiglia M, Grantz H, Saper CB, Schwartz ML, Leckman JF, Vaccarino FM (2005) Altered parvalbumin-positive neuron distribution in basal ganglia of individuals with Tourette syndrome. Proc Natl Acad Sci U S A 102:1330713312

Kaneko M, Sasahara M, Takayama S, Handa J, Hazama F (1998) Expression of platelet-derived growth factor after transient forebrain ischemia in the gerbil hippocampus. Acta Neuropathol 95:471-478

Kim HJ, Kim MH, Choe BK, Kim JW, Park JK, Cho AR, Bae H, Shin DH, Yim SV, Kwack K, Kwon YK, Chung JH (2008) Genetic association between 5'-upstream single-nucleotide polymorphisms of PDGFRB and schizophrenia in a Korean population. Schizophr Res 103:201-208

Kirby ML, Gale TF, Stewart DE (1983) Neural crest cells contribute to normal aorticopulmonary septation. Science 220:1059-1061

Komada Y, Yamane T, Kadota D, Isono K, Takakura N, Hayashi S, Yamazaki H (2012) Origins and properties of dental, thymic, and bone marrow mesenchymal cells and their stem cells. One 7:e46436

Kotecha SA, Oak JN, Jackson MF, Perez Y, Orser BA, Van Tol HH, MacDonald JF (2002) A D2 class dopamine receptor transactivates a receptor tyrosine kinase to inhibit NMDA receptor transmission. Neuron 35:1111-1122

Krupinski J, Issa R, Bujny T, Slevin M, Kumar P, Kumar S, Kaluza J (1997) A putative role for platelet-derived growth factor in angiogenesis and neuroprotection after ischemic stroke in humans. Stroke 28(3):564-573

Küçükkaya B, Haklar G, Yalçin AS (1996) NMDA excitotoxicity and free radical generation in rat brain homogenates: application of a chemiluminescence assay. Neurochem Res 21:1535-1538

Kwon HJ, Bhat N, Sweet EM, Cornell RA, Riley BB (2010) Identification of early requirements for preplacodal ectoderm and sensory organ development. PLoS Genet 6:e1001133

LaRochelle WJ, Jeffers M, McDonald WF, Chillakuru RA, Giese NA, Lokker NA, Sullivan C, Boldog FL, Yang M, Vernet C, Burgess CE, Fernandes E, Deegler LL, Rittman B, Shimkets J, Shimkets RA, Rothberg JM, Lichenstein HS (2001) PDGF-D, a new protease-activated growth factor. Nat Cell Biol 3:517-521

Le Douarin NM, Teillet MA, Catala M (1998) Neurulation in amniote vertebrates: a novel view deduced from the use of quail-chick chimeras. Int J Dev Biol 42:909-916

Le Lievre CS, Le Douarin NM (1975) Mesenchymal derivatives of the neural crest: analysis of chimaeric quail and chick embryos. J Embryol Exp Morpholog 34:125-154

Lei S, Lu WY, Xiong ZG, Orser BA, Valenzuela CF, MacDonald JF (1999) Platelet-derived growth factor receptor-induced feedforward inhibition of excitatory transmission between hippocampal pyramidal neurons. J Biol Chem 274:30617-30623

Leveen P, Pekny M, Gebre-Medhin S, Swolin B, Larsson E, Betsholtz C (1994) Mice deficient for PDGF B show renal, cardiovascular, and hematological abnormalities. Genes Dev 8:1875-1887

Lewis DA, Hashimoto T, Volk DW (2005) Cortical inhibitory neurons and schizophrenia. Nat Rev Neurosci 6:312-324

Li L, Bhatia R (2011) Stem cell quiescence. Clin Cancer Res 17:49364941 
Li X, Ponten A, Aase K, Karlsson L, Abramsson A, Uutela M, Backstrom G, Hellstrom M, Bostrom H, Li H, Soriano P, Betsholtz C, Heldin CH, Alitalo K, Ostman A, Eriksson U (2000) PDGF-C is a new protease-activated ligand for the PDGF alpha-receptor. Nat Cell Biol 2:302-309

Lindahl P, Johansson BR, Leveen P, Betsholtz C (1997a) Pericyte loss and microaneurysm formation in PDGF-B-deficient mice. Science 277:242-245

Lindahl P, Karlsson L, Hellstrom M, Gebre-Medhin S, Willetts K, Heath JK, Betsholtz C (1997b) Alveogenesis failure in PDGF-A-deficient mice is coupled to lack of distal spreading of alveolar smooth muscle cell progenitors during lung development. Development 124:39433953

Lois C, Alvarez-Buylla A (1993) Proliferating subventricular zone cells in the adult mammalian forebrain can differentiate into neurons and glia. Proc Natl Acad Sci U S A 90:2074-2077

Luo R, Gao J, Wehrle-Haller B, Henion PD (2003) Molecular identification of distinct neurogenic and melanogenic neural crest sublineages. Development 130:321-330

Ma Q, Huang B, Khatibi N, Rolland W 2nd, Suzuki H, Zhang JH, Tang J (2011) PDGFR-alpha inhibition preserves blood-brain barrier after intracerebral hemorrhage. Ann Neurol 70:920-931

Mazzarella L, Jorgensen HF, Soza-Ried J, Terry AV, Pearson S, Lacaud G, Kouskoff V, Merkenschlager M, Fisher AG (2011) Embryonic stem cell-derived hemangioblasts remain epigenetically plastic and require PRC1 to prevent neural gene expression. Blood 117:83-87

McCabe KL, Bronner-Fraser M (2008) Essential role for PDGF signaling in ophthalmic trigeminal placode induction. Development 135:1863-1874

Meletis K, Barnabe-Heider F, Carlen M, Evergren E, Tomilin N, Shupliakov O, Frisen J (2008) Spinal cord injury reveals multilineage differentiation of ependymal cells. PLoS Biol 6:e182

Menn B, Garcia-Verdugo JM, Yaschine C, Gonzalez-Perez O, Rowitch D, Alvarez-Buylla A (2006) Origin of oligodendrocytes in the subventricular zone of the adult brain. J Neurosci 26:7907-7918

Mercola M, Wang CY, Kelly J, Brownlee C, Jackson-Grusby L, Stiles C, Bowen-Pope D (1990) Selective expression of PDGF A and its receptor during early mouse embryogenesis. Dev Biol 138:114 122

Mohapel P, Frielingsdorf H, Häggblad J, Zachrisson O, Brundin P (2005) Platelet-derived growth factor (PDGF-BB) and brainderived neurotrophic factor (BDNF) induce striatal neurogenesis in adult rats with 6-hydroxydopamine lesions. Neuroscience 132(3):767-776

Morrison-Graham K, Schatteman GC, Bork T, Bowen-Pope DF, Weston JA (1992) A PDGF receptor mutation in the mouse (Patch) perturbs the development of a non-neuronal subset of neural crest-derived cells. Development 115:133-142

Mudhar HS, Pollock RA, Wang C, Stiles CD, Richardson WD (1993) PDGF and its receptors in the developing rodent retina and optic nerve. Development 118:539-552

Murtie JC, Zhou YX, Le TQ, Armstrong RC (2005a) In vivo analysis of oligodendrocyte lineage development in postnatal FGF2 null mice. Glia 49:542-554

Murtie JC, Zhou YX, Le TQ, Vana AC, Armstrong RC (2005b) PDGF and FGF2 pathways regulate distinct oligodendrocyte lineage responses in experimental demyelination with spontaneous remyelination. Neurobiol Dis 19:171-182

Nguyen PT, Nakamura T, Hori E, Urakawa S, Uwano T, Zhao J, Li R, Bac ND, Hamashima T, Ishii Y, Matsushima T, Ono T, Sasahara M, Nishijo H (2011) Cognitive and socio-emotional deficits in platelet-derived growth factor receptor- $\beta$ gene knockout mice. PLoS One 6:e18004

Nikkhah G, Odin P, Smits A, Tingström A, Othberg A, Brundin P, Funa K, Lindvall O (1993) Platelet-derived growth factor promotes survival of rat and human mesencephalic dopaminergic neurons in culture. Exp Brain Res 92:516-523

Nilsson MB, Zage PE, Zeng L, Xu L, Cascone T, Wu HK, Saigal B, Zweidler-McKay PA, Heymach JV (2010) Multiple receptor tyrosine kinases regulate HIF-1alpha and HIF-2alpha in normoxia and hypoxia in neuroblastoma: implications for antiangiogenic mechanisms of multikinase inhibitors. Oncogene 29:2938-2949

Nissen LJ, Cao R, Hedlund EM, Wang Z, Zhao X, Wetterskog D, Funa K, Brakenhielm E, Cao Y (2007) Angiogenic factors FGF2 and PDGF$\mathrm{BB}$ synergistically promote murine tumor neovascularization and metastasis. J Clin Invest 117:2766-2777

Noble M, Smith J, Power J, Mayer-Proschel M (2003) Redox state as a central modulator of precursor cell function. Ann N Y Acad Sci 991:251-271

Ohi Y, Ishii Y, Haji A, Noguchi S, Sasaoka T, Fujimori T, Nabeshima Y, Sasahara M, Hattori Y (2007) Platelet-derived growth factor (PDGF)-BB inhibits AMPA receptor-mediated synaptic transmission via PDGF receptor-beta in murine nucleus tractus solitarius. Brain Res 1159:77-85

Ohno M, Sasahara M, Narumiya S, Tanaka N, Yamano T, Shimada M, Hazama F (1999) Expression of platelet-derived growth factor Bchain and beta-receptor in hypoxic/ischemic encephalopathy of neonatal rats. Neuroscience 90:643-651

Orr-Urtreger A, Bedford MT, Do M-S, Eisenbach L, Lonai P (1992) Developmental expression of the a receptor for platelet-derived growth factor, which is deleted in the embryonic lethal Patch mutation. Development 115:289-303

Othberg A, Odin P, Ballagi A, Ahgren A, Funa K, Lindvall O (1995) Specific effects of platelet derived growth factor (PDGF) on fetal rat and human dopaminergic neurons in vitro. Exp Brain Res 105:111122

Paquet M, Kuwajima M, Yun CC, Smith Y, Hall RA (2006) Astrocytic and neuronal localization of the scaffold protein $\mathrm{Na}^{+} / \mathrm{H}^{+}$exchanger regulatory factor 2 (NHERF-2) in mouse brain. J Comp Neurol 494:752-762

Paul G, Ozen I, Christophersen NS, Reinbothe T, Bengzon J, Visse E, Jansson K, Dannaeus K, Henriques-Oliveira C, Roybon L, Anisimov SV, Renstrom E, Svensson M, Haegerstrand A, Brundin P (2012) The adult human brain harbors multipotent perivascular mesenchymal stem cells. PLoS One 7:e35577

Peng F, Dhillon NK, Yao H, Zhu X, Williams R, Buch S (2008) Mechanisms of platelet-derived growth factor-mediated neuroprotection-implications in HIV dementia. Eur J Neurosci 28:12551264

Peng F, Yao H, Bai X, Zhu X, Reiner BC, Beazely M, Funa K, Xiong $\mathrm{H}$, Buch S (2010) Platelet-derived growth factor-mediated induction of the synaptic plasticity gene Arc/Arg3.1. J Biol Chem 285:21615-21624

Peng F, Yao H, Akturk HK, Buch S (2012) Platelet-derived growth factor CC-mediated neuroprotection against HIV Tat involves TRPC-mediated inactivation of GSK 3beta. PLoS One 7:e47572

Pfister C, Pfrommer H, Tatagiba MS, Roser F (2012) Vascular endothelial growth factor signals through platelet-derived growth factor receptor beta in meningiomas in vitro. Br J Cancer 107:1702-1713

Pietz K, Odin P, Funa K, Lindvall O (1996) Protective effect of platelet-derived growth factor against 6-hydroxydopamineinduced lesion of rat dopaminergic neurons in culture. Neurosci Lett 204:101-104

Plemel JR, Chojnacki A, Sparling JS, Liu J, Plunet W, Duncan GJ, Park SE, Weiss S, Tetzlaff W (2011) Platelet-derived growth factor-responsive neural precursors give rise to myelinating oligodendrocytes after transplantation into the spinal cords of contused rats and dysmyelinated mice. Glia 59:1891-1910

Polito A, Reynolds R (2005) NG2-expressing cells as oligodendrocyte progenitors in the normal and demyelinated adult central nervous system. J Anat 207:707-716 
Raff MC, Lillien LE (1988) Differentiation of a bipotential glial progenitor cell: what controls the timing and the choice of developmental pathway? J Cell Sci Suppl 10:77-83

Raff MC, Lillien LE, Richardson WD, Burne JF, Noble MD (1988) Platelet-derived growth factor from astrocytes drives the clock that times oligodendrocyte development in culture. Nature 333:562-565

Reigstad LJ, Varhaug JE, Lillehaug JR (2005) Structural and functional specificities of PDGF-C and PDGF-D, the novel members of the platelet-derived growth factors family. FEBS J 272:5723-5741

Richardson WD, Pringle N, Mosley MJ, Westermark B, Dubois-Dalcq M (1988) A role for platelet-derived growth factor in normal gliogenesis in the central nervous system. Cell 53:309-319

Richarte AM, Mead HB, Tallquist MD (2007) Cooperation between the PDGF receptors in cardiac neural crest cell migration. Dev Biol 306:785-796

Saito Y, Tanaka Y, Aita Y, Ishii KA, Ikeda T, Isobe K, Kawakami Y, Shimano H, Hara H, Takekoshi K (2012) Sunitinib induces apoptosis in pheochromocytoma tumor cells by inhibiting VEGFR2/ Akt/mTOR/S6K1 pathways through modulation of Bcl-2 and BAD. Am J Physiol Endocrinol Metab 302:E615-E625

Sakata M, Yanamoto H, Hashimoto N, Iihara K, Tsukahara T, Taniguchi T, Kikuchi H (1998) Induction of infarct tolerance by platelet-derived growth factor against reversible focal ischemia. Brain Res 784:250-255

Sasahara M, Fries JW, Raines EW, Gown AM, Westrum LE, Frosch MP, Bonthron DT, Ross R, Collins T (1991) PDGF B-chain in neurons of the central nervous system, posterior pituitary, and in a transgenic model. Cell 64:217-227

Sasahara A, Kott JN, Sasahara M, Raines EW, Ross R, Westrum LE (1992) Platelet-derived growth factor B-chain-like immunoreactivity in the developing and adult rat brain. Brain Res Dev Brain Res 68:41-53

Sasahara M, Sato H, Iihara K, Wang J, Chue CH, Takayama S, Hayase Y, Hazama F (1995) Expression of platelet-derived growth factor B-chain in the mature rat brain and pituitary gland. Brain Res Mol Brain Res 32:63-74

Sasahara M, Amano S, Sato H, Yang JG, Hayase Y, Kaneko M, Sato I, Suzaki M, Hazama F (1998) Normal developing rat brain expresses a platelet-derived growth factor B chain (c-sis) mRNA truncated at the 5' end. Oncogene 16:1571-1578

Schatteman GC, Morrison-Graham K, van Koppen A, Weston JA, Bowen-Pope DF (1992) Regulation and role of PDGF receptor alpha-subunit expression during embryogenesis. Development 115:123-131

Servidei T, Riccardi A, Sanguinetti M, Dominici C, Riccardi R (2006) Increased sensitivity to the platelet-derived growth factor (PDGF) receptor inhibitor STI571 in chemoresistant glioma cells is associated with enhanced PDGF-BB-mediated signaling and STI571-induced Akt inactivation. J Cell Physiol 208:220-228

Shaw SH, Kelly M, Smith AB, Shields G, Hopkins PJ, Loftus J, Laval SH, Vita A, De Hert M, Cardon LR, Crow TJ, Sherrington R, DeLisi LE (1998) A genome-wide search for schizophrenia susceptibility genes. Am J Med Genet 81(5):364-376

Shen J, Ishii Y, Xu G, Dang TC, Hamashima T, Matsushima T, Yamamoto S, Hattori Y, Takatsuru Y, Nabekura J, Sasahara M (2012) PDGFR-beta as a positive regulator of tissue repair in a mouse model of focal cerebral ischemia. J Cereb Blood Flow Metab 32:353-367

Shim AH, Liu H, Focia PJ, Chen X, Lin PC, He X (2010) Structures of a platelet-derived growth factor/propeptide complex and a platelet-derived growth factor/receptor complex. Proc Natl Acad Sci U S A 107:11307-11312

Shioda N, Moriguchi S, Oya T, Ishii Y, Shen J, Matsushima T, Nishijo H, Sasahara M, Fukunaga K (2012) Aberrant hippocampal spine morphology and impaired memory formation in neuronal plateletderived growth factor beta-receptor lacking mice. Hippocampus 22:1371-1378

Silverman JM, Greenberg DA, Altstiel LD, Siever LJ, Mohs RC, Smith CJ, Zhou G, Hollander TE, Yang XP, Kedache M, Li G, Zaccario ML, Davis KL (1996) Evidence of a locus for schizophrenia and related disorders on the short arm of chromosome 5 in a large pedigree. Am J Med Genet 67:162-171

Sjöborg M, Pietz K, Ahgren A, Yamada N, Lindvall O, Funa K, Odin P (1998) Expression of platelet-derived growth factor after intrastriatal ibotenic acid injury. Exp Brain Res 119:245250

Sklar P, Pato MT, Kirby A, Petryshen TL, Medeiros H, Carvalho C, Macedo A, Dourado A, Coelho I, Valente J, Soares MJ, Ferreira CP, Lei M, Verner A, Hudson TJ, Morley CP, Kennedy JL, Azevedo MH, Lander E, Daly MJ, Pato CN (2004) Genomewide scan in Portuguese Island families identifies 5q31-5q35 as a susceptibility locus for schizophrenia and psychosis. Mol Psychiatry 9(2):213-218

Smits A, Kato M, Westermark B, Nistér M, Heldin CH, Funa K (1991) Neurotrophic activity of platelet-derived growth factor (PDGF): rat neuronal cells possess functional PDGF beta-type receptors and respond to PDGF. Proc Natl Acad Sci U S A 88:81598163

Smits A, Ballagi AE, Funa K (1993) PDGF-BB exerts trophic activity on cultured GABA interneurons from the newborn rat cerebellum. Eur J Neurosci 5:986-994

Soriano P (1997) The PDGF alpha receptor is required for neural crest cell development and for normal patterning of the somites. Development 124:2691-2700

Su EJ, Fredriksson L, Geyer M, Folestad E, Cale J, Andrae J, Gao Y, Pietras K, Mann K, Yepes M, Strickland DK, Betsholtz C, Eriksson U, Lawrence DA (2008) Activation of PDGF-CC by tissue plasminogen activator impairs blood-brain barrier integrity during ischemic stroke. Nat Med 14:731-737

Sun T, Jayatilake D, Afink GB, Ataliotis P, Nister M, Richardson WD, Smith HK (2000) A human YAC transgene rescues craniofacial and neural tube development in PDGFRalpha knockout mice and uncovers a role for PDGFRalpha in prenatal lung growth. Development 127:4519-4529

Svitkina T, Lin WH, Webb DJ, Yasuda R, Wayman GA, Van Aelst L, Soderling SH (2010) Regulation of the postsynaptic cytoskeleton: roles in development, plasticity, and disorders. J Neurosci 30:14937-14942

Takashima Y, Era T, Nakao K, Kondo S, Kasuga M, Smith AG, Nishikawa S (2007) Neuroepithelial cells supply an initial transient wave of MSC differentiation. Cell 129:1377-1388

Tallquist MD, Soriano P (2003) Cell autonomous requirement for PDGFRalpha in populations of cranial and cardiac neural crest cells. Development 130:507-518

Tang Z (2010) Survival effect of PDGF-CC rescues neurons from apoptosis in both brain and retina by regulating GSK3beta phosphorylation. J Exp Med 207:867-880

Tang Z, Arjunan P, Lee C, Li Y, Kumar A, Hou X, Wang B, Wardega P, Zhang F, Dong L, Zhang Y, Zhang SZ, Ding H, Fariss RN, Becker KG, Lennartsson J, Nagai N, Cao Y, Li X (2010) Survival effect of PDGF-CC rescues neurons from apoptosis in both brain and retina by regulating GSK3beta phosphorylation. J Exp Med 207:867-880

Theisen CS, Wahl JK 3rd, Johnson KR, Wheelock MJ (2007) NHERF links the $\mathrm{N}$-cadherin/catenin complex to the platelet-derived growth factor receptor to modulate the actin cytoskeleton and regulate cell motility. Mol Biol Cell 18:1220-1232

Toma JG, McKenzie IA, Bagli D, Miller FD (2005) Isolation and characterization of multipotent skin-derived precursors from human skin. Stem Cells 23:727-737 
Tseng HC, Dichter MA (2005) Platelet-derived growth factor-BB pretreatment attenuates excitotoxic death in cultured hippocampal neurons. Neurobiol Dis 19:77-83

Tsunekawa S, Ohi Y, Ishii Y, Sasahara M, Haji A (2009) Hypoxic ventilatory response in platelet-derived growth factor receptorbeta-knockout mice. J Pharmacol Sci 110:270-275

Valenzuela CF, Xiong Z, MacDonald JF, Weiner JL, Frazier CJ, Dunwiddie TV, Kazlauskas A, Whiting PJ, Harris RA (1996) Platelet-derived growth factor induces a long-term inhibition of $\mathrm{N}$-methyl-D-aspartate receptor function. J Biol Chem 271:16151-16159

Vasefi MS, Kruk JS, Heikkila JJ, Beazely MA (2013) 5-hydroxytryptamine type 7 receptor neuroprotection against NMDA-induced excitotoxicity is PDGF $\beta$ receptor dependent. J Neurochem 125:2636

Wang Y, Zhang WY, Hu S, Lan F, Lee AS, Huber B, Lisowski L, Liang P, Huang M, de Almeida PE, Won JH, Sun N, Robbins RC, Kay MA, Urnov FD, Wu JC (2012) Genome editing of human embryonic stem cells and induced pluripotent stem cells with zinc finger nucleases for cellular imaging. Circ Res 111:1494-1503

Weston JA, Yoshida H, Robinson V, Nishikawa S, Fraser ST (2004) Neural crest and the origin of ectomesenchyme: neural fold heterogeneity suggests an alternative hypothesis. Dev Dyn 229:118-130
Whitelaw A (2000) Systematic review of therapy after hypoxic-ischaemic brain injury in the perinatal period. Semin Neonatol 5:33-40

Xu G, Shen J, Ishii Y, Fukuchi M, Dang TC, Zheng Y, Hamashima T, Fujimori T, Tsuda M, Funa K, Sasahara M (2013) Functional analysis of platelet-derived growth factor receptor-beta in neural stem/progenitor cells. Neuroscience 238:195-208

Yao H, Peng F, Fan Y, Zhu X, Hu G, Buch SJ (2009) TRPC channelmediated neuroprotection by PDGF involves Pyk2/ERK/CREB pathway. Cell Death Differ 16:1681-1693

Yeh HJ, Ruit KG, Wang YX, Parks WC, Snider WD, Deuel TF (1991) PDGF A-chain gene is expressed by mammalian neurons during development and in maturity. Cell 64:209-216

Zhang SX, Gozal D, Sachleben LR Jr, Rane M, Klein JB, Gozal E (2003) Hypoxia induces an autocrine-paracrine survival pathway via platelet-derived growth factor (PDGF)-B/PDGF-beta receptor/ phosphatidylinositol 3-kinase/Akt signaling in RN46A neuronal cells. FASEB J 17:1709-1711

Zheng L, Ishii Y, Tokunaga A, Hamashima T, Shen J, Zhao QL, Ishizawa S, Fujimori T, Nabeshima Y, Mori H, Kondo T, Sasahara M (2010) Neuroprotective effects of PDGF against oxidative stress and the signaling pathway involved. J Neurosci Res 88:1273-1284

Zlokovic BV (2010) Neurodegeneration and the neurovascular unit. Nat Med 16:1370-1371 